Article

\title{
Enhancement of the formic acid electrooxidation activity of palladium using graphene/carbon black binary carbon supports
}

\author{
Meiying Lv, Wenpeng Li *, Huiling Liu, Wenjuan Wen, Guang Dong, Jinghua Liu, Kaichen Peng \\ Institute of Advanced Energy Materials and Chemistry, Key Lab of Fine Chemicals in Universities of Shandong, School of Chemistry and Pharmaceutical \\ Engineering, Qilu University of Technology, Jinan 250353, Shandong, China
}

A R T I C L E I N F O

Article history:

Received 25 December 2016

Accepted 6 April 2017

Published 5 May 2017

\section{Keywords:}

Binary carbon support

Palladium

Graphene

Carbon black

Formic acid oxidation

Fuel cell

\begin{abstract}
A B S T R A C T
Combinations of graphene (Gr) and carbon black (C) were employed as binary carbon supports to fabricate Pd-based electrocatalysts via one-pot co-reduction with $\mathrm{Pd}^{2+}$. The electrocatalytic performance of the resulting $\mathrm{Pd} / \mathrm{Gr}-\mathrm{C}$ catalysts during the electrooxidation of formic acid was assessed. A $\mathrm{Pd} / \mathrm{Gr}_{0.3} \mathrm{C}_{0.7}$ ( $\mathrm{Gr}$ oxide: $\mathrm{C}=3: 7$, based on the precursor mass ratio) electrocatalyst exhibited better catalytic performance than both $\mathrm{Pd} / \mathrm{C}$ and $\mathrm{Pd} / \mathrm{Gr}$ catalysts. The current density generated by the $\mathrm{Pd} / \mathrm{Gr}_{0.3} \mathrm{C}_{0.7}$ catalyst was as high as $102.14 \mathrm{~mA} \mathrm{mgPd}^{-1}$, a value that is approximately 3 times that obtained from the Pd/C $\left(34.40 \mathrm{~mA} \mathrm{mg}_{\mathrm{Pd}}{ }^{-1}\right)$ and 2.6 times that of the Pd/Gr material $(38.50 \mathrm{~mA}$ $\mathrm{mg}_{\mathrm{Pd}}{ }^{-1}$ ). The anodic peak potential of the $\mathrm{Pd} / \mathrm{Gr}_{0.3} \mathrm{C}_{0.7}$ was $120 \mathrm{mV}$ more negative than that of the $\mathrm{Pd} / \mathrm{C}$ and $70 \mathrm{mV}$ more negative than that of the Pd/Gr. Scanning electron microscopy images indicated that the spherical $\mathrm{C}$ particles accumulated on the wrinkled graphene surfaces to form $\mathrm{C}$ cluster/Gr hybrids having three-dimensional nanostructures. X-ray photoelectron spectroscopy data confirmed the interaction between the Pd metal and the binary Gr-C support. The $\mathrm{Pd} / \mathrm{Gr}_{0.3} \mathrm{C}_{0.7}$ also exhibited high stability, and so is a promising candidate for the fabrication of anodes for direct formic acid fuel cells. This work demonstrates a simple and cost-effective method for improving the performance of Pd-based electrocatalysts, which should have potential industrial applications.
\end{abstract}

(C) 2017, Dalian Institute of Chemical Physics, Chinese Academy of Sciences. Published by Elsevier B.V. All rights reserved.

\section{Introduction}

The electrooxidation of formic acid has been studied for more than half a century [1]. In recent years, direct formic acid fuel cells (DFAFCs) have been the subject of considerable research interest as clean power sources. Pd is currently considered a state-of-the-art electrocatalyst for DFAFCs [2] because it exhibits higher catalytic activity and lower CO poisoning than Pt during the anode oxidation of formic acid $[3,4]$. A drawback of Pd as an electrocatalyst for formic acid oxidation (FAO) is its instability [5]. In addition, the activity of Pd catalyst must be improved. Various approaches to increasing the catalytic activity/stability of Pd-based electrocatalysts and reducing the required quantity of this metal have been examined, and are summarized in our previous report [6], which cites more than 90 literature publications. These methods include the use of bimetallic and trimetallic Pd-based catalysts $[7,8]$ and nano-sized catalysts, such as the recently reported nano-complex structures [9]. Another effective means of enhancing the catalytic performance of electrocatalysts is the selection of appropriate support materials [10].

The materials used as supports for electrocatalysts include,

\footnotetext{
* Corresponding author. Tel: +86-531-89631208; Fax: +86-531-89631207; E-mail: liwenpeng@qlu.edu.cn, wenpengli75@163.com This work was supported by the Natural Science Foundation of Shandong Province (ZR2016BM31), the Science and Technology Foundation of Jinan City (201311035).

DOI: 10.1016/S1872-2067(17)62834-1 | http://www.sciencedirect.com/science/journal/18722067 | Chin. J. Catal., Vol. 38, No. 5, May 2017
} 
but are not limited to, carbon-based materials [11-18], transition metal oxides [19-24], conducting polymers [25,26], carbon nitride [27], tungsten carbide [28,29] and silicon [30]. Carbon materials are being continuously developed, including carbon black (C) [11], carbon nanotubes [12], carbon nanofibers [13], mesoporous carbon [14], graphene (Gr) [15], diamond film [16], $\mathrm{C}_{60}$ [17] and carbon aerogel [18]. Among these carbon supports, $\mathrm{C}$ is the most widely used $[31,32]$ because of its high surface area, good electrical conductivity, stability and low cost. Investigations into improving the performance of $\mathrm{Pd} / \mathrm{C}$ catalyst have primarily focused on tailoring the metal particles, such as by changing the alloy composition or nanostructure. We have reported carbon-supported binary Pd-Cr alloy [33] and ternary $\mathrm{Pd}-\mathrm{Cu}-\mathrm{Fe}$ composites, fabricated by the partial galvanic sacrifice of an alloy template [6], as electrocatalysts for FAO. Past studies have demonstrated that some Pd-based binary alloy or ternary metal composites exhibit better catalytic performance than unitary Pd catalysts. This raises the question: can the use of binary or ternary carbon supports obtained by combining different carbon materials improve the electrocatalytic performance relative to that obtained from a unitary carbon support?

Yang et al. [34] have reported that Pd nanoparticles supported on $\mathrm{Gr}$ nanosheets-multiwalled carbon nanotubes (Pd/GNS-CNTs) hybrid supports exhibit high electrocatalytic performance during FAO. We therefore anticipated that $\mathrm{C}$ could have advantages when combined with $\mathrm{Gr}$ to form a binary support, because spherical $\mathrm{C}$ particles are readily situated on two-dimensional planar graphene surfaces to form three-dimensional (3D) nanostructures. In contrast, one-dimensional carbon nanotubes tend to lie flat on the $\mathrm{Gr}$ plane. In addition, the cost of $\mathrm{C}$ is less than that of either carbon nanotubes or $\mathrm{Gr}$, which is beneficial with regard to potential industrial applications. Thus, the concept of Pd catalysts loaded on binary carbon supports comprised of $\mathrm{Gr}$ and $\mathrm{C}(\mathrm{Pd} / \mathrm{Gr}-\mathrm{C})$ attracted our attention.

In the present study, C and Gr were used to fabricate binary carbon supports for Pd. Following the emergence of Gr as an ideal catalyst support material in 2009, it has become one of the most widely researched subjects in the field of fuel cells [35]. Many methods have been established for Gr synthesis, such as mechanical exfoliation [36], epitaxial growth [37], chemical vapor deposition (CVD) [38], reduction of Gr oxide (G0) [39], unzipping of carbon nanotubes [40] and intercalation [41]. However, most of these methods involve high costs and low yields. The reduction of GO is regarded as an effective means of producing Gr with high yields [42], and so we fabricated $\mathrm{Pd} / \mathrm{Gr}-\mathrm{C}$ electrocatalysts in this work via the one-pot reduction of a mixture of $\mathrm{Pd}, \mathrm{C}$ and GO. Among the materials tested, the $\mathrm{Pd} / \mathrm{Gr}_{0.3} \mathrm{C}_{0.7}$ catalyst was found to exhibit the highest catalytic activity and stability during FAO. Compared with $\mathrm{Pd} / \mathrm{C}$, the anodic peak potential during FAO of the $\mathrm{Pd} / \mathrm{Gr}_{0.3} \mathrm{C}_{0.7}$ was shifted by $120 \mathrm{mV}$, while the current density of this new catalyst (102.14 $\mathrm{mA} \mathrm{mgPd}^{-1}$ ) was about three times that of the $\mathrm{Pd} / \mathrm{C}$ (34.40 $\mathrm{mA} \mathrm{mg}_{\mathrm{Pd}}{ }^{-1}$ ). These results indicate superior electrocatalytic activity throughout the FAO reaction.

To the best of our knowledge, this paper represents the first report of the application of binary $\mathrm{Gr} / \mathrm{C}$ supports to the anode oxidation of formic acid. Huang and co-workers [43] demonstrated that $\mathrm{C}$ mixed with $\mathrm{Pt}$ loaded on reduced GO (Pt/rGO) greatly improved the electrocatalytic activity and stability during the oxygen reduction reaction. However, Pt is only supported on the rGO planes in this material, while there is no $\mathrm{Pt}$ on the $\mathrm{C}$. The $\mathrm{C}$ is inserted between the rGO layers. In contrast, in the case of our Pd/Gr-C catalysts, Pd nanoparticles are loaded not only on the $\mathrm{Gr}$ but also on the $\mathrm{C}$ clusters, resulting in a 3D distribution. This more extensive 3D distribution of Pd nanoparticles allows the reactant molecules to more easily reach the active sites on the noble metal surfaces, thus improving the catalytic performance. Moreover, this study confirmed the presence of interactions between the Pd metal and the binary Gr-C support. This work therefore represents a simple and cost-effective approach to improving the performance of Pd-based electrocatalysts intended for industrial applications.

\section{Experimental}

\subsection{Materials}

Palladium (II) chloride $\left(\mathrm{PdCl}_{2}, \mathrm{Pd} \geq 59.0 \%\right)$ was purchased from the Sinopharm Chemical Reagent Co., Ltd., while Vulcan carbon powder (XC-72R) was obtained from the Cabot Corp. Graphite flakes (natural, -325 mesh, 99.8\%) were purchased from Alfa Aesar (Tianjin, China) and Nafion (5 wt\%) was purchased from the America Dupont Co. All other chemicals were analytical grade and were used as-received without further purification. Triple-distilled water was used throughout.

\subsection{Synthesis of the $P d / G r-C$ and $P d / C$ catalysts}

The Pd/Gr-C catalysts were prepared by a one-pot $\mathrm{NaBH}_{4}$ method. GO was synthesized from the graphite flakes according to an improved version of Hummers' method [44]. Following this, the required amount of Vulcan carbon black was added to a constantly stirred GO solution to obtain the desired mass ratio. Subsequently, the required amount of a $\mathrm{PdCl}_{2}$ solution was added to the suspension. The Pd metal loading on the $\mathrm{GO} / \mathrm{C}$ combination was $20 \mathrm{wt} \%$. The $\mathrm{pH}$ of the suspension was adjusted to 10 by the dropwise addition of $1 \mathrm{~mol} \mathrm{~L}^{-1} \mathrm{NaOH}$. After adding $10 \mathrm{~mL}$ of a $\mathrm{NaBH}_{4}$ solution (5 wt\%) to the suspension, the resulting reaction mixture was stirred for $6 \mathrm{~h}$ and then allowed to stand for $1 \mathrm{~h}$. Following these procedures, the resulting $\mathrm{Pd} / \mathrm{Gr}-\mathrm{C}$ slurry was filtered, thoroughly washed with triple-distilled water, and finally dried in a vacuum oven at 50 ${ }^{\circ} \mathrm{C}$ for $10 \mathrm{~h}$. It should be noted that $\mathrm{Pd} / \mathrm{Gr}_{0.1} \mathrm{C}_{0.9}, \mathrm{Pd} / \mathrm{Gr}_{0.3} \mathrm{C}_{0.7}$, $\mathrm{Pd} / \mathrm{Gr}_{0.5} \mathrm{C}_{0.5}$ and $\mathrm{Pd} / \mathrm{Gr}_{0.7} \mathrm{C}_{0.3}$ catalysts were obtained by using GO:C mass ratios of $1: 9,3: 7,5: 5$ and 7:3, respectively. These values were not necessarily the final mass ratios of the $\mathrm{rGO}$ and C since the accurate separation of Gr and C in the final Pd/Gr-C catalysts was difficult. For comparison purposes, $\mathrm{Pd} / \mathrm{Gr}$ and $\mathrm{Pd} / \mathrm{C}$ catalysts were prepared using the same reduction procedure.

\subsection{Preparation of the working electrode}


A glassy carbon (GC) electrode (3 $\mathrm{mm}$ in diameter) was polished with $0.05 \mu \mathrm{m}$ alumina $\left(\mathrm{Al}_{2} \mathrm{O}_{3}\right)$ to a mirror finish and washed with triple-distilled water prior to each experiment. Subsequently, $6 \mathrm{mg}$ portion of the catalyst was added to a mixture of $0.3 \mathrm{~mL}$ deionized water and $0.3 \mathrm{~mL}$ ethanol and the mixture was ultrasonically agitated for $30 \mathrm{~min}$ to obtain an ink. Following this, $20 \mu \mathrm{L}(4 \mu \mathrm{L} \times 5$ aliquots $)$ of this mixture was dropped by micropipette onto the surface of the GC electrode. The deposited ink was allowed to dry in air and was then covered with $4 \mu \mathrm{L}$ of a Nafion solution (5 wt\%) and again dried at room temperature. The as-prepared catalyst-modified GC electrode was employed as the working electrode in our experiments.

\subsection{Physical characterization}

X-ray diffraction (XRD) patterns were obtained using a Bruker D8 Advance instrument (Bruker, Germany) with $\mathrm{Cu} \mathrm{K}_{\alpha}$ radiation at $\lambda=0.15406 \mathrm{~nm}$. Scanning electron microscopy (SEM) images were obtained with a Hitachi SU-70 microscope. The morphology of each product was assessed by transmission electron microscopy (TEM, JEOL JEM-1011) at an acceleration voltage of $200 \mathrm{kV}$. High-resolution transmission electron microscopy (HR-TEM) was carried out with a JEOL JEM 2100. Raman spectra were recorded on a JY HR800 multi-channel confocal microspectrometer (HORIBA Jobin Yvon, Paris, France) with $514 \mathrm{~nm}$ laser excitation. X-ray photoelectron spectroscopy (XPS) was performed with a Kratos XSAM-800 spectrometer with $\mathrm{Mg} K_{\alpha}$ radiation. Catalyst compositions were determined via inductively coupled plasma-atom emission spectrometry (ICP-AES, iCAP7000 series).

\subsection{Electrochemical measurements}

The electrochemical measurements were performed with a CHI832B electrochemical workstation (CH Instruments, Austin, Texas) and a conventional three-electrode cell at room temperature. The three-electrode cell consisted of a carbon-rod serving as the counter electrode, a $\mathrm{Hg} / \mathrm{Hg}_{2} \mathrm{SO}_{4}$ (saturated $\mathrm{K}_{2} \mathrm{SO}_{4}$ ) electrode serving as the reference electrode and a GC electrode ( $3 \mathrm{~mm}$ in diameter) coated with the catalyst, serving as the working electrode. All the potentials in this paper are reported with respect to a reversible hydrogen electrode (RHE). Cyclic voltammetry curves were acquired in $0.5 \mathrm{~mol} \mathrm{~L}^{-1}$ $\mathrm{H}_{2} \mathrm{SO}_{4}$ at a scan rate of $10 \mathrm{mV} \mathrm{s}^{-1}$. Linear sweep voltammetry (LSV) plots and chronoamperometry data were obtained in a solution of $0.5 \mathrm{~mol} \mathrm{~L}^{-1} \mathrm{HCOOH}$ in $0.5 \mathrm{~mol} \mathrm{~L}^{-1} \mathrm{H}_{2} \mathrm{SO}_{4}$ at a scan rate of $10 \mathrm{mV} \mathrm{s}^{-1}$. All electrolyte solutions were deaerated with bubbling $\mathrm{N}_{2}$ for more than 20 min just prior to use and maintained under a $\mathrm{N}_{2}$ atmosphere throughout the entire experimental procedure.

\section{Results and discussion}

\subsection{Characterization of $P d / G r-C$ and $P d / C$ catalysts}

The actual Pd concentrations in the various samples were evaluated by ICP-AES analysis, and the $\mathrm{Pd} / \mathrm{C}, \mathrm{Pd} / \mathrm{Gr}$, $\mathrm{Pd} / \mathrm{Gr}_{0.1} \mathrm{C}_{0.9}, \mathrm{Pd} / \mathrm{Gr}_{0.3} \mathrm{C}_{0.7}, \mathrm{Pd} / \mathrm{Gr}_{0.5} \mathrm{C}_{0.5}$ and $\mathrm{Pd} / \mathrm{Gr}_{0.7} \mathrm{C}_{0.3}$ catalysts were found to have metal loadings of 20.22, 20.35, 20.12, 20.12, 20.10, and $20.06 \mathrm{wt} \%$, respectively. The Pd loading of each catalyst was therefore approximately $20 \%$. The crystal structure of each sample was determined by XRD, and Fig. 1 presents their XRD patterns. The peaks at approximately $25^{\circ}$ are assigned to the $\mathrm{C}(002)$ plane [45]. The four peaks at $2 \theta=40^{\circ}$, $46^{\circ}, 68^{\circ}$ and $82^{\circ}$ are characteristic of a face-centered-cubic (fcc) structure, corresponding to the (111), (200), (220) and (311) crystalline planes of $\mathrm{Pd}$ [46], respectively. Compared with the $\mathrm{Pd} / \mathrm{C}$ pattern, the characteristic $\mathrm{Pd}(220)$ peaks in the $\mathrm{Pd} / \mathrm{Gr}-\mathrm{C}$ and $\mathrm{Pd} / \mathrm{Gr}$ patterns are shifted to higher $2 \theta$ values, indicating decreased lattice constants and shrinkage of the Pd lattices [47]. Nearly all XRD peaks generated by the Pd/Gr-C can be attributed to $\mathrm{Pd} / \mathrm{Gr}$. An examination of XRD data in various publications [34,48-51] demonstrated that almost all the XRD peaks of catalysts supported on hybrids made of graphene and other materials (such as Pd/GNS-CNTs [34], Pd/NS-G [48] and $\mathrm{Pd} / \mathrm{rGO}-$ MWCNTs [49]) matched those generated by our Pd/Gr catalyst. However, it is difficult to explain this phenomenon. The Gr is known to undergo significant metal-support interactions [52], thus we speculate that it has a greater effect on the Pd lattice constant than the $\mathrm{C}$ in the Gr-C hybrids. The XPS data also confirmed interactions between the Pd and the binary $\mathrm{Gr}-\mathrm{C}$ support, as discussed further on. The lattice constant $(a)$ of the $\mathrm{Pd}$ nanoparticles was calculated from the diffraction peak position $\left(\theta_{\max }\right)$ using the Eq. (1) [42]:

$$
a=\frac{\sqrt{2} \lambda}{\sin \theta_{\max }}
$$

The $\operatorname{Pd}(220)$ peak was chosen for the calculation of lattice constants because it appears at approximately $68^{\circ}$ and thus is far from the background signal of the $C$ support in the XRD patterns [53]. The Pd lattice constants were found to be approximately $0.391 \mathrm{~nm}$ for the $\mathrm{Pd} / \mathrm{Gr}-\mathrm{C}$ and $\mathrm{Pd} / \mathrm{Gr}$ catalysts and $0.398 \mathrm{~nm}$ for the Pd/C. Huang et al. [53] have demonstrated that the lattice constants of Pd nanoparticles have an obvious effect on the catalytic performance during FAO. The crystallite sizes of the Pd nanoparticles in the direction perpendicular to the lattice planes were also calculated from the $\operatorname{Pd}(220)$ dif-

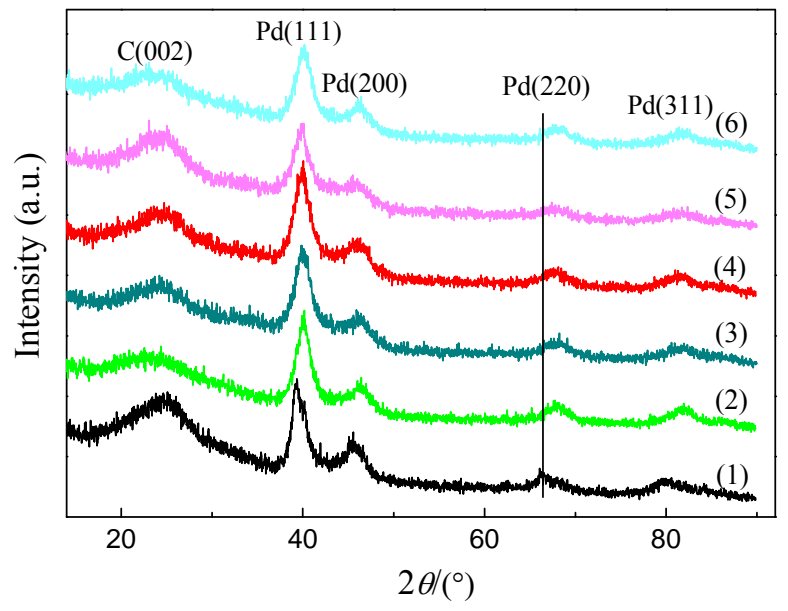

Fig. 1. XRD patterns of $\mathrm{Pd} / \mathrm{C}(1), \mathrm{Pd} / \mathrm{Gr}(2), \mathrm{Pd} / \mathrm{Gr}_{0.1} \mathrm{C}_{0.9}(3), \mathrm{Pd} / \mathrm{Gr}_{0.3} \mathrm{C}_{0.7}$ (4), $\mathrm{Pd} / \mathrm{Gr}_{0.5} \mathrm{C}_{0.5}(5)$, and $\mathrm{Pd} / \mathrm{Gr}_{0.7} \mathrm{C}_{0.3}(6)$ catalysts. 
fraction peaks using Scherrer's equation [54], and were determined to be $5.5,4.6,3.8,4.1,4.3$ and $4.1 \mathrm{~nm}$ for the $\mathrm{Pd} / \mathrm{C}$, $\mathrm{Pd} / \mathrm{Gr}, \mathrm{Pd} / \mathrm{Gr}_{0.1} \mathrm{C}_{0.9}, \mathrm{Pd} / \mathrm{Gr}_{0.3} \mathrm{C}_{0.7}, \mathrm{Pd} / \mathrm{Gr}_{0.5} \mathrm{C}_{0.5}$ and $\mathrm{Pd} / \mathrm{Gr}_{0.7} \mathrm{C}_{0.3}$ catalysts, respectively.

From the SEM image of the $\mathrm{Pd} / \mathrm{Gr}_{0.3} \mathrm{C}_{0.7}$ catalyst in Fig. 2, it is evident that the spherical $\mathrm{C}$ particles accumulated on the wrinkled surface of the Gr to form a C cluster/Gr hybrid with a 3D structure. It has been reported that reduced $\mathrm{Gr}$ sheets tend to form irreversible agglomerates through van der Waals interactions and can even restack to form graphite $[34,55]$. As can be seen, the $\mathrm{C}$ clusters effectively hinder the restacking of the $\mathrm{Gr}$ layers, thus retaining the outstanding single-layer electric properties of the material. The $\mathrm{C}$ clusters also prevent the wrinkled/curved surfaces of neighboring $\mathrm{Gr}$ sheets from forming enclosed spaces, which facilitates the movement of reactant/product molecules. The lateral resolution of SEM is typically on the order of $3 \mathrm{~nm}$, and so it is difficult to observe Pd nanoparticles directly in the SEM image, although these nanoparticles can readily be identified with TEM (Fig. 3).

Fig. 3 presents TEM images and particle size distribution histograms for the $\mathrm{Pd} / \mathrm{C}, \mathrm{Pd} / \mathrm{Gr}$ and $\mathrm{Pd} / \mathrm{Gr}_{0.3} \mathrm{C}_{0.7}$ catalysts. Fig. 3(d) provides the standard deviation (SD) error bars associated with the histograms that indicate the mean particle size deviations. The $\mathrm{Pd} / \mathrm{Gr}_{0.3} \mathrm{C}_{0.7}$ catalyst was selected for these analyses because it exhibited the best performance during FAO, as discussed further on. As shown in Fig. 3(C), the dispersion of the $\mathrm{Pd}$ nanoparticles on the surface of the $\mathrm{Gr}_{0.3} \mathrm{C}_{0.7}$ binary support was slightly more uniform than that on the $\mathrm{Pd} / \mathrm{C}$ and $\mathrm{Pd} / \mathrm{Gr}$ catalysts. The average diameters of the particles in the $\mathrm{Pd} / \mathrm{C}$, $\mathrm{Pd} / \mathrm{Gr}$ and $\mathrm{Pd} / \mathrm{Gr}_{0.3} \mathrm{C}_{0.7}$ catalysts as determined from the TEM images were $5.6,4.7$, and $4.0 \mathrm{~nm}$, respectively, and these values are consistent with the XRD results. Furthermore, the HR-TEM image of the $\mathrm{Pd} / \mathrm{Gr}_{0.3} \mathrm{C}_{0.7}$ catalyst in Fig. 3(D) shows well-resolved lattice fringes with spacing of $0.222,0.138$ and $0.188 \mathrm{~nm}$, which correspond to the (111), (220) and (200) planes of Pd crystals [56], respectively.

Fig. 4 shows the Raman spectra of the $\mathrm{Pd} / \mathrm{Gr}$ and $\mathrm{Pd} / \mathrm{Gr}_{0.3} \mathrm{C}_{0.7}$ specimens. The two prominent peaks seen in these spectra, D $\left(1330 \mathrm{~cm}^{-1}\right)$ and $\mathrm{G}\left(1590 \mathrm{~cm}^{-1}\right)$, are normally attributed to the presence of defects or edge areas and in-plane $s p^{2}$ hybridized carbon atoms [57], respectively. It is worth noting that the intensity ratio $\left(I_{\mathrm{D}} / I_{\mathrm{G}}\right)$ in the $\mathrm{Pd} / \mathrm{Gr}_{0.3} \mathrm{C}_{0.7}$ spectrum is smaller than that in the $\mathrm{Pd} / \mathrm{Gr}$ spectrum, indicating an increased degree of crystallinity in the Gr [42], which can be ascribed to the steric effect of the $\mathrm{C}$ clusters. Because of their sin-

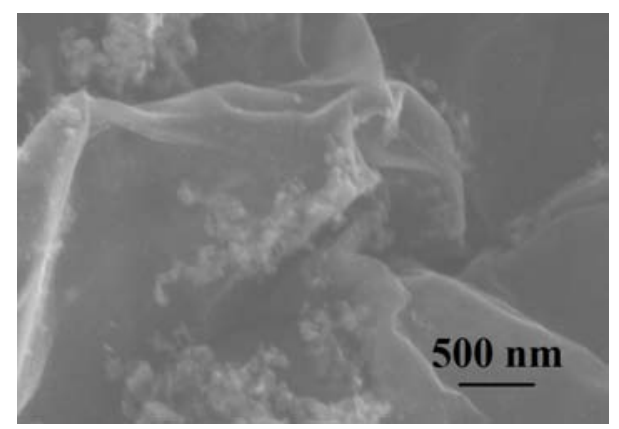

Fig. 2. SEM image of the $\mathrm{Pd} / \mathrm{Gr}_{0.3} \mathrm{C}_{0.7}$ catalyst.
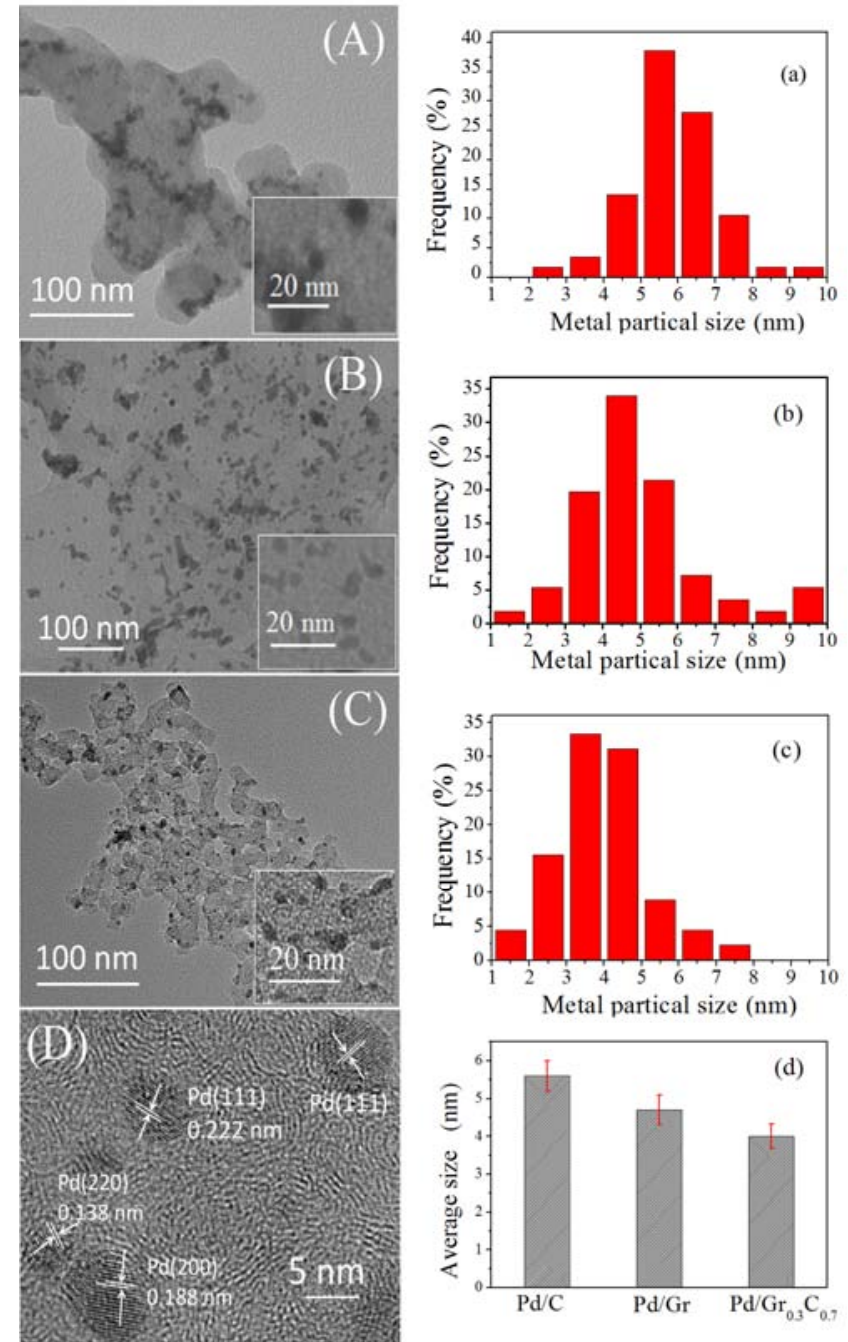

Fig. 3. TEM images of $\mathrm{Pd} / \mathrm{C}(\mathrm{A}), \mathrm{Pd} / \mathrm{Gr}(\mathrm{B})$ and $\mathrm{Pd} / \mathrm{Gr}_{0.3} \mathrm{C}_{0.7}(\mathrm{C})$, and an HR-TEM image (D) of $\mathrm{Pd} / \mathrm{Gr}_{0.3} \mathrm{C}_{0.7}$. Particle size distribution histograms of $\mathrm{Pd} / \mathrm{C}(\mathrm{a}), \mathrm{Pd} / \mathrm{Gr}(\mathrm{b})$ and $\mathrm{Pd} / \mathrm{Gr}_{0.3} \mathrm{C}_{0.7}$ (c), and a histogram of average particle sizes with standard deviation (SD) error bars (d).

gle-atom-thick structure, Gr nanosheets have a tendency to undergo irreversible agglomeration via overlapping as a result of $\pi-\pi$ stacking and van der Waals forces, even to the extent of



Fig. 4. Raman spectra of the $\mathrm{Pd} / \mathrm{Gr}(1)$ and $\mathrm{Pd} / \mathrm{Gr}_{0.3} \mathrm{C}_{0.7}(2)$. 
restacking to form graphite $[34,58]$. This effect can severely restrict the usefulness of this material as a catalyst support. As noted, the $\mathrm{C}$ clusters inhibited the stacking of the $\mathrm{Gr}$ nanosheets. Consequently, a greater quantity of oxygen-containing functional groups could be removed by chemical reduction to form a more orderly crystal structure, which is consistent with the XPS results discussed below.

The surface elemental compositions of the $\mathrm{Pd} / \mathrm{C}, \mathrm{Pd} / \mathrm{Gr}$ and $\mathrm{Pd} / \mathrm{Gr}_{0.3} \mathrm{C}_{0.7}$ composites were determined by XPS, with the results provided in Fig. 5. All the XPS profiles were fitted by the Gaussian-Lorentzian (20\% Gaussian) method after background subtraction using Shirley's method [59]. The survey spectra of the $\mathrm{Pd} / \mathrm{C}, \mathrm{Pd} / \mathrm{Gr}$ and $\mathrm{Pd} / \mathrm{Gr}_{0.3} \mathrm{C}_{0.7}$ displayed in Fig. 5(A) all show three peaks located at approximately 284, 338 and $531 \mathrm{eV}$, corresponding to $\mathrm{C} 1 s, \mathrm{Pd} 3 d$ and $01 s$. Fig. 5(B) presents the $\mathrm{C}$ $1 s$ spectra of $\mathrm{Pd} / \mathrm{Gr}$ and $\mathrm{Pd} / \mathrm{Gr}_{0.3} \mathrm{C}_{0.7}$ samples. The $\mathrm{C} 1 s$ binding energy is further separated into five peaks at 284.7, 286.1, 287.8, 289.1 and $291.1 \mathrm{eV}$, corresponding to the $\mathrm{C}-\mathrm{C}, \mathrm{C}-\mathrm{O}, \mathrm{C}=\mathrm{O}$, $\mathrm{O}-\mathrm{C}=\mathrm{O}$ and $\pi \rightarrow \pi^{*}$ groups $[60,61]$, respectively. Density functional theory (DFT) calculations confirmed that the presence of both defects and oxygen-containing species on the graphene surface could play important roles in improving the catalyst's stability [62]. The relative percentages of the various carbon species obtained from the peak areas are summarized in Table 1. The concentrations of oxygen-containing functional group atoms in the $\mathrm{Pd} / \mathrm{Gr}$ and $\mathrm{Pd} / \mathrm{Gr}_{0.3} \mathrm{C}_{0.7}$ composites were $29.81 \%$ and $22.88 \%$, respectively. Due to the intercalation of the $\mathrm{C}$ between the Gr layers in the $\mathrm{Pd} / \mathrm{Gr}_{0.3} \mathrm{C}_{0.7}$, the oxygen group content was reduced in comparison with that in the $\mathrm{Pd} / \mathrm{Gr}$ catalyst. The Pd 3d XPS (Fig. 5(C)) spectra can be deconvoluted into two sets of peaks corresponding to $\mathrm{Pd} 3 d_{5 / 2}(\sim 335.8 \mathrm{eV})$ and $\mathrm{Pd}$ $3 d_{3 / 2}(\sim 341.0 \mathrm{eV})$. The peaks at relatively lower binding energy values (at approximately 335.6 and $340.8 \mathrm{eV}$ ) are attributed to metallic $\mathrm{Pd}\left(\mathrm{Pd}^{0}\right)$ while the other set of double peaks (at approximately 337.2 and $342.6 \mathrm{eV}$ ) results from $\mathrm{Pd}(\mathrm{II}) \mathrm{O}$. It should be noted that the Pd $3 d_{5 / 2}$ binding energy of the Pd/Gro.3 $\mathrm{C}_{0.7}$ (336.08 eV) was significantly shifted in the positive direction (by approximately 0.23 and $0.30 \mathrm{eV}$ ) relative to the values for
Table 1

The relative percentages of the various carbon species as determined from C $1 s$ spectra.

\begin{tabular}{lcc}
\hline Catalyst & C specie & Atom \% \\
\hline $\mathrm{Pd} / \mathrm{Gr}$ & $\mathrm{C}-\mathrm{C}$ & 61.2 \\
& $\mathrm{C}-\mathrm{O}$ & 15.86 \\
& $\mathrm{C}=\mathrm{O}$ & 5.87 \\
& $\mathrm{O}-\mathrm{C}=\mathrm{O}$ & 8.08 \\
$\pi \rightarrow \pi^{*}$ & 8.99 \\
$\mathrm{Pd} / \mathrm{Gr}_{0.3} \mathrm{C}_{0.7}$ & $\mathrm{C}-\mathrm{C}$ & 74.1 \\
& $\mathrm{C}-\mathrm{O}$ & 12.96 \\
& $\mathrm{C}=\mathrm{O}$ & 4.96 \\
& $\mathrm{O}-\mathrm{C}=\mathrm{O}$ & 4.96 \\
& $\pi \rightarrow \pi^{*}$ & 3.03 \\
\hline
\end{tabular}

the Pd/Gr (335.85 eV) and Pd/C (335.78 eV) catalysts. This positive shift suggests a decrease in the $3 d$ electron density of the Pd [33], which can be attributed to the strong interaction between the Pd nanocrystals and the support [60]. Pd having a lower $3 d$ electron density does not bind to the $\mathrm{COOH}$ intermediates as readily, such that the surface $(\mathrm{COOH})_{\text {ads }}$ coverage is decreased. For this reason, the FAO reaction would be expected to proceed primarily via the direct pathway [63] on the as-prepared $\mathrm{Pd} / \mathrm{Gr}-\mathrm{C}$ catalysts. The finding that the $\mathrm{Pd} 3 d$ binding energy of the $\mathrm{Pd} / \mathrm{Gr}_{0.3} \mathrm{C}_{0.7}$ was more positive than those of the $\mathrm{Pd} / \mathrm{Gr}$ and the $\mathrm{Pd} / \mathrm{C}$ confirms the interaction between the $\mathrm{Pd}$ metal and the binary Gr-C support. Based on the relative peak areas, the $\mathrm{Pd}^{0}: \mathrm{PdO}$ ratio in the $\mathrm{Pd} / \mathrm{Gr}_{0.3} \mathrm{C}_{0.7}$ catalyst was estimated to be 1.44 , indicating that the Pd surfaces were partially oxidized, presumably as the result of exposure to ambient air. It is known that nano-sized Pd particles are readily oxidized in ambient atmospheres.

\subsection{Electrochemical analysis of $P d / G r-C$ and $P d / C$ catalysts}

Cyclic voltammetry (CV) was used to estimate the electrochemical active surface areas (ECSAs) of the Pd catalysts. Fig. 6 shows the cyclic voltammograms of $\mathrm{Pd} / \mathrm{C}, \mathrm{Pd} / \mathrm{Gr}, \mathrm{Pd} / \mathrm{Gr}_{0.1} \mathrm{C}_{0.9}$,
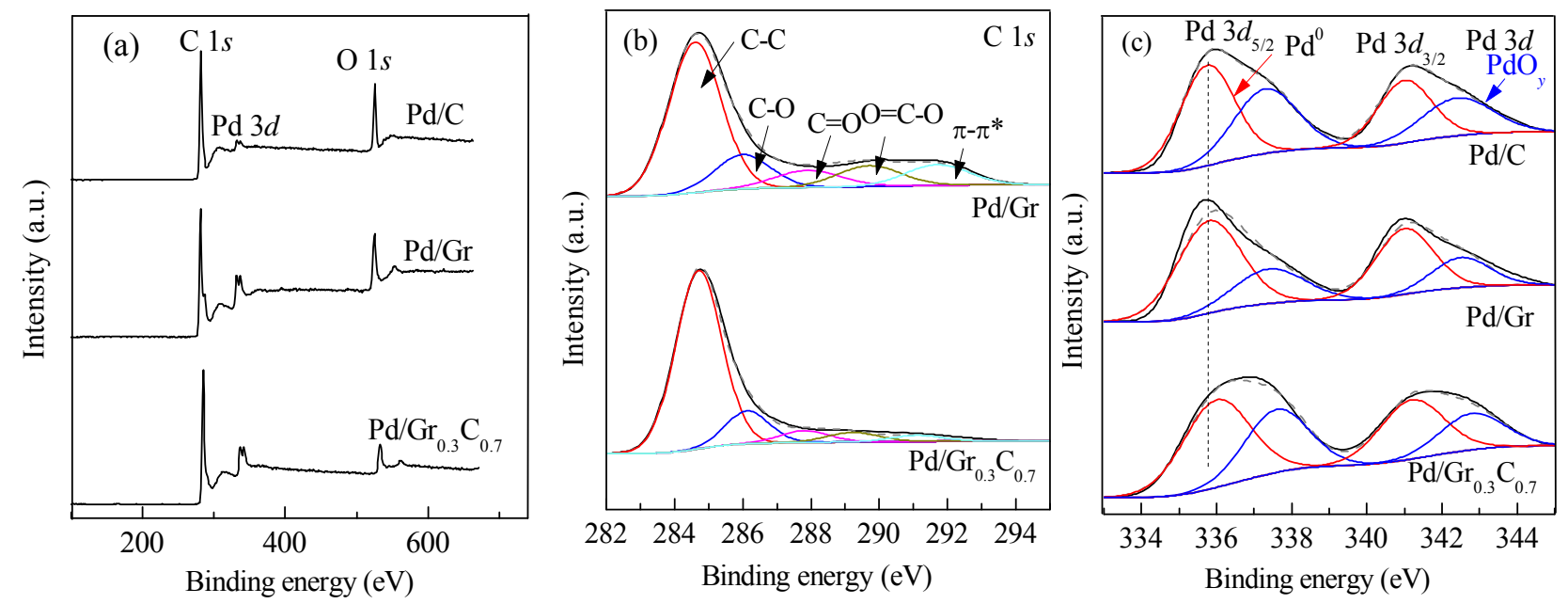

Fig. 5. XPS spectra of the $\mathrm{Pd} / \mathrm{C}, \mathrm{Pd} / \mathrm{Gr}$ and $\mathrm{Pd} / \mathrm{Gr}_{0.3} \mathrm{C}_{0.7}$ catalysts. 


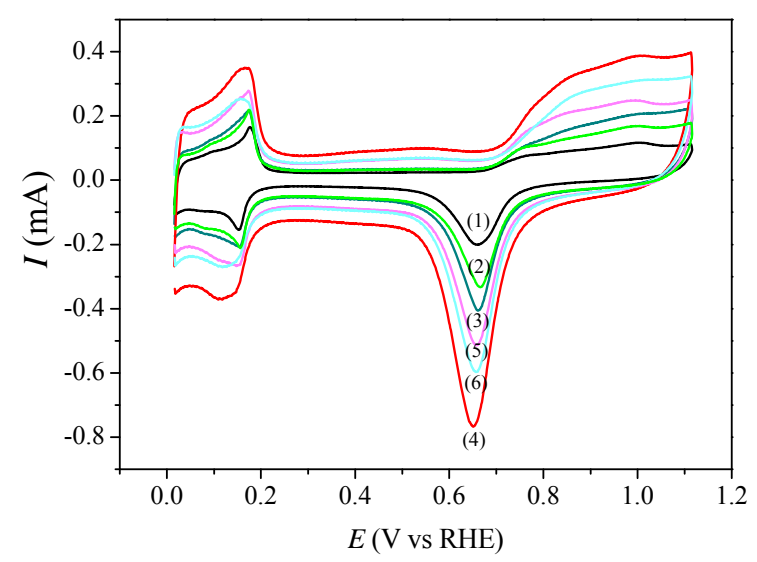

Fig. 6. The $\mathrm{CV}$ curves of the $\mathrm{Pd} / \mathrm{C}(1), \mathrm{Pd} / \mathrm{Gr}$ (2), $\mathrm{Pd} / \mathrm{Gr}_{0.1} \mathrm{C}_{0.9}$ (3), $\mathrm{Pd} / \mathrm{Gr}_{0.3} \mathrm{C}_{0.7}$ (4), $\mathrm{Pd} / \mathrm{Gr}_{0.5} \mathrm{C}_{0.5}$ (5), and $\mathrm{Pd} / \mathrm{Gr}_{0.7} \mathrm{C}_{0.3}$ (6) catalysts in $0.5 \mathrm{~mol}$ $\mathrm{L}^{-1} \mathrm{H}_{2} \mathrm{SO}_{4}$ at a scan rate of $10 \mathrm{mV} \mathrm{s}^{-1}$.

$\mathrm{Pd} / \mathrm{Gr}_{0.3} \mathrm{C}_{0.7}, \mathrm{Pd} / \mathrm{Gr}_{0.5} \mathrm{C}_{0.5}$ and $\mathrm{Pd} / \mathrm{Gr}_{0.7} \mathrm{C}_{0.3}$ catalysts acquired at a scan rate of $10 \mathrm{mV} \mathrm{s}^{-1}$ in a $\mathrm{H}_{2} \mathrm{SO}_{4}$ solution $\left(0.5 \mathrm{~mol} \mathrm{~L}^{-1}\right)$. Because of the ability of bulk Pd to absorb hydrogen, it is difficult to calculate the ECSA due to the presence of a monolayer of adsorbed hydrogen. Therefore, the ECSA of the Pd electrode was calculated by determining the coulombic charge associated with the reduction of $\mathrm{Pd}(\mathrm{II})$ oxide [64]. The peak in the potential range from 0.5 to $0.8 \mathrm{~V}$ is assigned to the reduction of $\mathrm{Pd}(\mathrm{II})$ oxide. The ECSA value of each electrocatalyst was found using the Eq. (2) [6]:

$$
E C S A=Q_{\mathrm{R}} / Q_{\mathrm{MR}}
$$

where $Q_{\mathrm{R}}$ is the coulombic charge associated with the peak due to the reduction of $\mathrm{Pd}(\mathrm{II})$ oxide, and $Q_{\mathrm{MR}}$ is the charge $(0.424$ $\mathrm{mC} \mathrm{cm}-2$ ) associated with the reduction of a Pd(II) oxide monolayer. The resulting ECSA values are provided in Table 2. It is evident that the $\mathrm{Pd} / \mathrm{Gr}-\mathrm{C}$ catalysts had larger ECSAs than the $\mathrm{Pd} / \mathrm{C}$ and $\mathrm{Pd} / \mathrm{Gr}$ electrocatalysts.

Fig. 7 compares the FAO performance of the $\mathrm{Pd} / \mathrm{C}, \mathrm{Pd} / \mathrm{Gr}$ and Pd/Gr-C catalysts, as assessed by LSV in $0.5 \mathrm{~mol} \mathrm{~L}^{-1} \mathrm{H}_{2} \mathrm{SO}_{4}$ $+0.5 \mathrm{~mol} \mathrm{~L}^{-1} \mathrm{HCOOH}$. The main peak at approximately 0.2 to $0.5 \mathrm{~V}$ is attributed to FAO via the direct pathway, while the small shoulder near $0.8 \mathrm{~V}$ is ascribed to the oxidation of adsorbed $\mathrm{CO}$ via the indirect pathway. The peak potentials of the $\mathrm{Pd} / \mathrm{Gr}-\mathrm{C}$ electrocatalysts during FAO are initially negatively shifted and subsequently positively shifted with increases in the $\mathrm{C}$ content (inset in Fig. 7) in the mixture of $\mathrm{GO}$ and $\mathrm{C}$ prior to $\mathrm{NaBH}_{4}$ reduction. The peak potential of the $\mathrm{Pd} / \mathrm{Gr}_{0.3} \mathrm{C}_{0.7}$ is 120 and $70 \mathrm{mV}$ more negative than those of the $\mathrm{Pd} / \mathrm{C}$ and $\mathrm{Pd} / \mathrm{Gr}$ catalysts (Table 2). At a peak potential of $0.23 \mathrm{~V}$, the current density of the $\mathrm{Pd} / \mathrm{Gr}_{0.3} \mathrm{C}_{0.7}$ catalyst was $102.14 \mathrm{~mA} \mathrm{mgPd}^{-1}$, a value that is approximately 3 and 2.6 times those generated by the Pd/C (34.40 mA mg $\left.{ }_{P d}{ }^{-1}\right)$ and Pd/Gr (38.50 $\left.\mathrm{mA} \mathrm{mg}_{\mathrm{Pd}}{ }^{-1}\right)$, in-

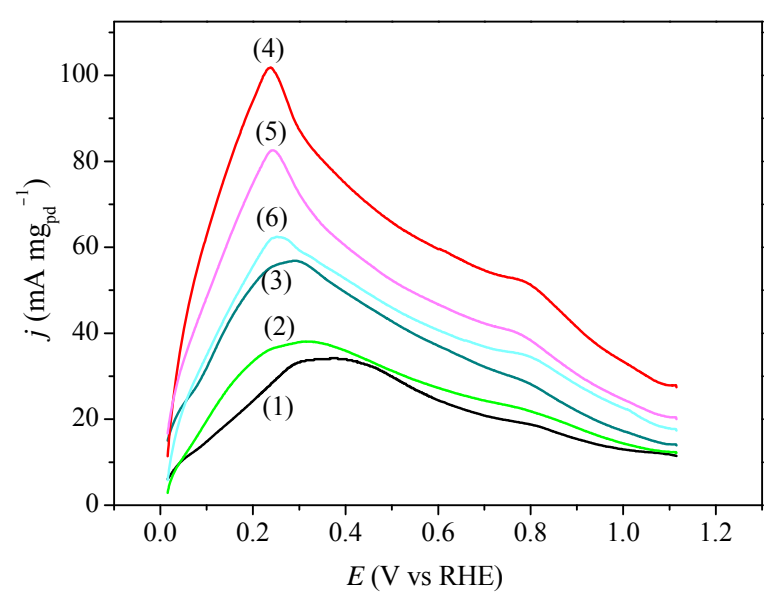

Fig. 7. The LSV curves of the $\mathrm{Pd} / \mathrm{C}(1), \mathrm{Pd} / \mathrm{Gr}$ (2), $\mathrm{Pd} / \mathrm{Gr}_{0.1} \mathrm{C}_{0.9}$ (3), $\mathrm{Pd} / \mathrm{Gr}_{0.3} \mathrm{C}_{0.7}$ (4), $\mathrm{Pd} / \mathrm{Gr}_{0.5} \mathrm{C}_{0.5}$ (5), and $\mathrm{Pd} / \mathrm{Gr}_{0.7} \mathrm{C}_{0.3}$ (6) catalysts in 0.5 mol L ${ }^{-1} \mathrm{HCOOH}+0.5 \mathrm{~mol} \mathrm{~L}^{-1} \mathrm{H}_{2} \mathrm{SO}_{4}$ at a scan rate of $10 \mathrm{mV} \mathrm{s}^{-1}$.

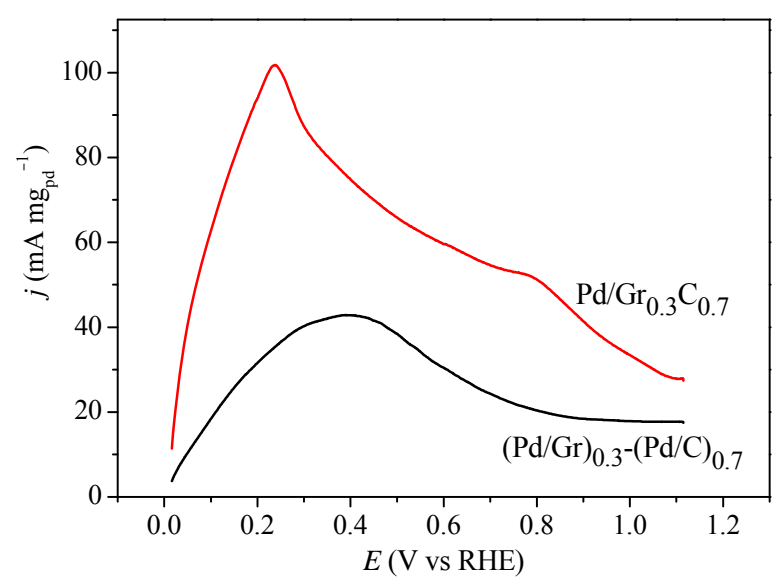

Fig. 8. The LSV curves of $\mathrm{Pd} / \mathrm{Gr}_{0.3} \mathrm{C}_{0.7}$ and physically mixed $\mathrm{Pd} / \mathrm{Gr}$ and $\mathrm{Pd} / \mathrm{C}$ catalysts in $0.5 \mathrm{~mol} \mathrm{~L}^{-1} \mathrm{HCOOH}+0.5 \mathrm{~mol} \mathrm{~L}^{-1} \mathrm{H}_{2} \mathrm{SO}_{4}$ at a scan rate of $10 \mathrm{mV} \mathrm{s}^{-1}$.

dicating higher catalytic activity during FAO (Table 2). The $\mathrm{Pd} / \mathrm{Gr}_{0.3} \mathrm{C}_{0.7}$ peak is also much sharper than those of the other catalysts, suggesting that more active sites were accessible [65]. The SEM image in Fig. 2 demonstrated that the binary Gr-C support formed a 3D nanostructure, which assists in loading the Pd nanoparticles. As noted, the more extensive 3D distribution of Pd allowed reactant molecules to more easily reach the active sites on the Pd surface, thus improving the catalytic performance. The XPS analysis described earlier also supports the enhanced catalytic activity of the $\mathrm{Pd} / \mathrm{Gr}_{0.3} \mathrm{C}_{0.7}$ catalyst.

For comparison purposes, the performance of physically mixed $\mathrm{Pd} / \mathrm{Gr}$ and $\mathrm{Pd} / \mathrm{C}$ catalysts (made at $\mathrm{Pd} /$ support mass ratios of 3:7) is provided in Fig. 8 . It can be seen that the

Table 2

Electrochemical data for the $\mathrm{Pd} / \mathrm{C}, \mathrm{Pd} / \mathrm{Gr}, \mathrm{Pd} / \mathrm{Gr}_{0.1} \mathrm{C}_{0.9}, \mathrm{Pd} / \mathrm{Gr}_{0.3} \mathrm{C}_{0.7}, \mathrm{Pd} / \mathrm{Gr}_{0.5} \mathrm{C}_{0.5}$ and $\mathrm{Pd} / \mathrm{Gr}_{0.7} \mathrm{C}_{0.3}$ catalysts.

\begin{tabular}{|c|c|c|c|c|c|c|}
\hline Catalyst & $\mathrm{Pd} / \mathrm{C}$ & $\mathrm{Pd} / \mathrm{Gr}$ & $\mathrm{Pd} / \mathrm{Gr}_{0.1} \mathrm{C}_{0.9}$ & $\mathrm{Pd} / \mathrm{Gr}_{0.3} \mathrm{C}_{0.7}$ & $\mathrm{Pd} / \mathrm{Gr}_{0.5} \mathrm{C}_{0.5}$ & $\mathrm{Pd} / \mathrm{Gr}_{0.7} \mathrm{C}_{0.3}$ \\
\hline $\operatorname{ECSA}\left(\mathrm{cm}^{2}\right)$ & 5.04 & 6.37 & 8.24 & 13.24 & 8.53 & 11.06 \\
\hline Peak potential $(E / \mathrm{V})$ & 0.35 & 0.30 & 0.27 & 0.23 & 0.24 & 0.25 \\
\hline Peak current density $\left(j_{\mathrm{p}} / \mathrm{mA} \mathrm{mg}_{\mathrm{Pd}}{ }^{-1}\right)$ & 34.40 & 38.50 & 57.38 & 102.14 & 82.84 & 63.12 \\
\hline CA terminal current $\left(\mathrm{mA} \mathrm{mg}_{\mathrm{Pd}}{ }^{-1}\right)$ & 5.80 & 11.20 & - & 16.50 & - & - \\
\hline
\end{tabular}




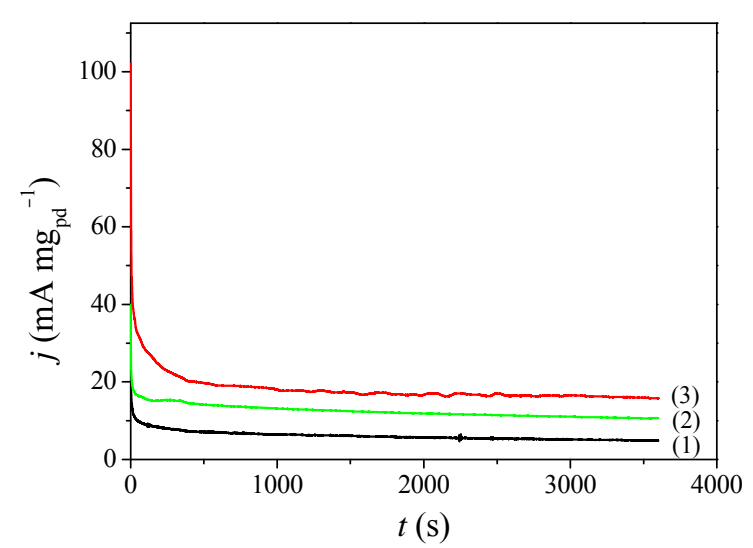

Fig. 9. The chronoamperometric curves of the $\mathrm{Pd} / \mathrm{C}(1), \mathrm{Pd} / \mathrm{Gr}(2)$ and $\mathrm{Pd} / \mathrm{Gr}_{0.3} \mathrm{C}_{0.7}$ (3) in $0.5 \mathrm{~mol} \mathrm{~L}-1 \mathrm{HCOOH}+0.5 \mathrm{~mol} \mathrm{~L}^{-1} \mathrm{H}_{2} \mathrm{SO}_{4}$ at $0.3 \mathrm{~V}$ (vs. RHE).

Pd/Gro.3 $\mathrm{C}_{0.7}$ catalyst had a more negative peak potential and a larger current density than the mixture, demonstrating superior catalytic activity.

To evaluate the stability of the $\mathrm{Pd} / \mathrm{Gr}_{0.3} \mathrm{C}_{0.7}$ catalyst, chronoamperometry (CA) experiments were carried out at $0.3 \mathrm{~V}$ vs. RHE for 3600 s. Fig. 9 shows the chronoamperometric curves for the $\mathrm{Pd} / \mathrm{C}, \mathrm{Pd} / \mathrm{Gr}$ and $\mathrm{Pd} / \mathrm{Gr}_{0.3} \mathrm{C}_{0.7}$ catalysts in $0.5 \mathrm{~mol} \mathrm{~L}^{-1}$ $\mathrm{H}_{2} \mathrm{SO}_{4}+0.5 \mathrm{~mol} \mathrm{~L}-1$ HCOOH. The current density decreased rapidly in the initial stage, possibly due to deactivation of the Pd electrocatalyst by adsorption of $\mathrm{CO}$ or CO-like intermediates during the FAO process [66]. The current density subsequently stabilized, and the stable current density generated by the $\mathrm{Pd} / \mathrm{Gr}_{0.3} \mathrm{C}_{0.7}$ catalyst was higher than those of the $\mathrm{Pd} / \mathrm{C}$ and $\mathrm{Pd} / \mathrm{Gr}$ (Table 2). Thus, the $\mathrm{Pd} / \mathrm{Gr}_{0.3} \mathrm{C}_{0.7}$ catalyst was more stable than either the $\mathrm{Pd} / \mathrm{C}$ or $\mathrm{Pd} / \mathrm{Gr}$.

The Fig. 10(a) shows the LSV data obtained in $0.5 \mathrm{~mol} \mathrm{~L}^{-1}$ $\mathrm{H}_{2} \mathrm{SO}_{4}+0.5 \mathrm{~mol} \mathrm{~L}{ }^{-1} \mathrm{HCOOH}$ for the $\mathrm{Pd} / \mathrm{Gr}_{0.3} \mathrm{C}_{0.7}$ electrode at different scan rates during FAO. The relationship between the peak current density $\left(j_{\mathrm{p}}\right)$ and the square root of the scan rate $\left(v^{1 / 2}\right)$ at the $\mathrm{Pd} / \mathrm{Gr}_{0.3} \mathrm{C}_{0.7}$ electrode is plotted in Fig. $10(\mathrm{~b})$. These data demonstrate that the oxidation potential and $j_{\mathrm{p}}$ were both increased with increasing scan rates. This result suggests that the rate-determining step of $\mathrm{FAO}$ on the $\mathrm{Pd} / \mathrm{Gr}_{0.3} \mathrm{C}_{0.7}$ electrode is an irreversible electrode process. In addition, a linear relationship is evident between $j_{\mathrm{p}}$ and $v^{1 / 2}$, further confirming that

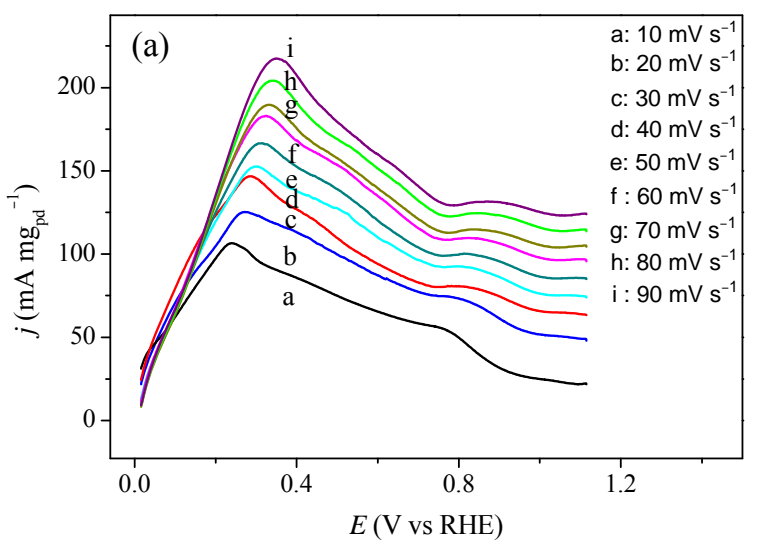

the FAO is an irreversible electrode process [67].

\section{Conclusions}

This work demonstrated the successful fabrication of binary Gr-C supports for Pd nanoparticles by a one-pot chemical reduction method. The resulting $\mathrm{Pd} / \mathrm{Gr}-\mathrm{C}$ catalysts exhibit improved electrocatalytic performance compared with $\mathrm{Pd} / \mathrm{C}$ and $\mathrm{Pd} / \mathrm{Gr}$ catalysts during FAO. The superior performance of the $\mathrm{Pd} / \mathrm{Gr}-\mathrm{C}$ can be attributed to its intrinsic 3D nanostructure, in which $\mathrm{C}$ clusters effectively hinder the restacking of $\mathrm{Gr}$, thus retaining the outstanding single-layer electric properties of $\mathrm{Gr}$ and facilitating the movement of reactant/product molecules. Furthermore, the strong interaction between the Pd nanoparticles and binary Gr-C support reduce the Pd $3 d$ electron density. As a result, the $\mathrm{Pd}$ does not readily bind $\mathrm{COOH}$ intermediates, and FAO proceeds largely via the direct pathway. The as-prepared $\mathrm{Pd} / \mathrm{Gr}_{0.3} \mathrm{C}_{0.7}$ catalyst shows the highest activity and good stability, and so binary Gr-C appears to be a promising candidate as a support material for noble metal-based catalysts.

\section{References}

[1] M. W. Breiter, Electrochim. Acta, 1963, 8, 447-456.

[2] J. F. Chang, L. G. Feng, C. P. Liu, W. Xing, X. L. Hu, Angew. Chem. Int. Ed., 2014, 53, 122-126.

[3] J. Y. Cao, Z. T. Zhu, W. F. Zhao, J. Xu, Z. D. Chen, Chin. J. Chem., 2016, 34, 1-7.

[4] M. C. Li, W. Y. Wang, C. A. Ma, Chin. J. Catal., 2009, 30, 1073-1075.

[5] W. S. Jung, J. Han, S. Ha, J. Power Sources, 2007, 173, 53-59.

[6] B. Y. Yu, W. J. Wen, W. P. Li, Y. Yang, D. D. Hou, C. S. Liu, Electrochim. Acta, 2016, 196, 223-230.

[7] S. Z. Hu, L. Scudiero, S. Ha, Electrochim. Acta, 2012, 83, 354-358.

[8] S. Z. Hu, F. Munoz, J. Noborikawa, J. Haan, L. Scudiero, S. Ha, Appl. Catal. B, 2016, 180, 758-765.

[9] G. A. El-Nagar, A. F. Darweesh, I. Sadiek, Electrochim. Acta, 2016, 215, 334-338.

[10] J. Goel, S. Basu, Int. J. Hydrogen Energy, 2014, 39, 15956-15966.

[11] Q. Wang, Y. X. Liao, H. Y. Zhang, J. Li, W. Zhao, S. L. Chen, J. Power Sources, 2015, 292, 72-77.

[12] S. D. Yang, X. G. Zhang, H. Y. Mi, X. G. Ye, J. Power Sources, 2008, 175, 26-32.

[13] D. Liu, Q. H. Guo, H. Q. Hou, O. Niwa, T. Y. You, ACS Catal., 2014, 4,

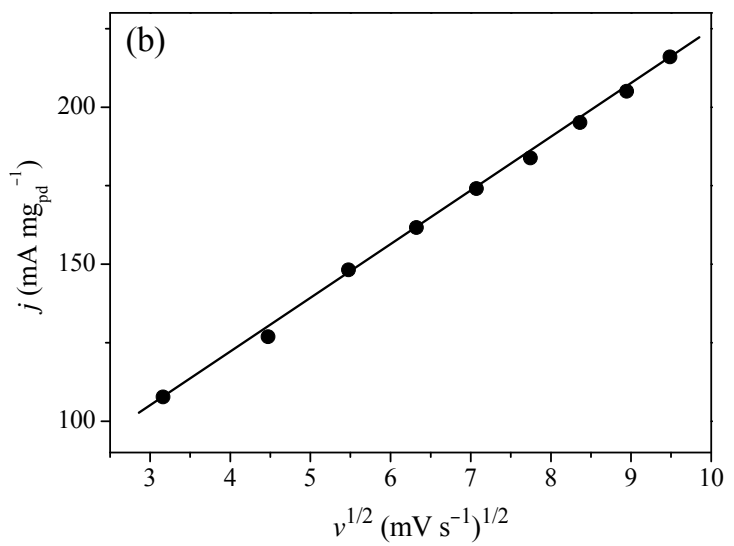

Fig. 10. LSV curves (a) acquired during FAO on the $\mathrm{Pd} / \mathrm{Gr}_{0.3} \mathrm{C}_{0.7}$ electrode in $0.5 \mathrm{~mol} \mathrm{~L} \mathrm{HCOOH}^{-1} \mathrm{HC} 0.5 \mathrm{~mol} \mathrm{~L}^{-1} \mathrm{H}_{2} \mathrm{SO}_{4}$ at different scan rates. The peak current density as a function of the square root of the scan rate (b). 


\section{Graphical Abstract}

Chin. J. Catal., 2017, 38: 939-947 doi: 10.1016/S1872-2067(17)62834-1

Enhancement of the formic acid electrooxidation activity of palladium using graphene/carbon black binary carbon supports

Meiying Lv, Wenpeng Li *, Huiling Liu, Wenjuan Wen, Guang Dong, Jinghua Liu, Kaichen Peng

Qilu University of Technology

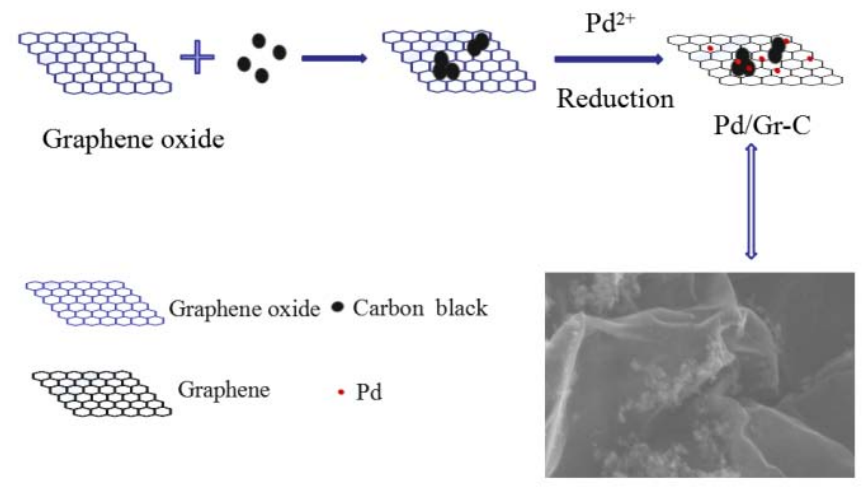

Composite catalysts consisting of Pd loaded on binary graphene/carbon black supports were synthesized by a reduction method. These materials exhibit better electrocatalytic performance than either Pd/carbon black or Pd/graphene catalysts, suggesting a new approach to binary carbon supports for noble metal-based catalysts with fuel cell applications.

$1825-1829$.

[14] C. T. Hung, Z. H. Liou, P. Veerakumar, P. H. Wu, T. C. Liu, S. B. Liu, Chin. J. Catal., 2016, 37, 43-53.

[15] Y. Zhou, X. C. Hu, Q. Z. Fan, H. R. Wen, J. Mater. Chem. A, 2016, 4, 4587-4591.

[16] T. Arunagiri, T. D. Golden, O. Chyan, Mater. Chem. Phys., 2005, 92, 152-158.

[17] B. Özdamar, M. Boero, C. Massobrio, D. Felder-Flesch, S. Le Roux, J. Chem. Phys., 2015, 143, 114308.

[18] J. L. Figueiredo, M. F. R. Pereira, J. Energy Chem., 2013, 22, 195-201.

[19] W. C. Xu, S. L. Zhu, Z. Y. Li, Z. D. Cui, X. J. Yang, Electrochim. Acta, 2013, 114, 35-41.

[20] Z. H. Zhang, Y. J. Huang, J. J. Ge, C. P. Liu, T. H. Lu, W. Xing, Electrochem. Commun., 2008, 10, 1113-1116.

[21] L. G. Feng, L. Yan, Z. M. Cui, C. P. Liu, W. Xing, J. Power Sources, 2011, 196, 2469-2474.

[22] J. C. Jia, R. F. Wang, H. Wang, S. Ji, J. L. Key, V. Linkov, K. Shi, Z. Q. Lei, Catal. Commun., 2011, 16, 60-63.

[23] H. T. Lu, Y. Fan, P. Huang, D. L. Xu, J. Power Sources, 2012, 215, 48-52.

[24] H. T. Lu, Z. J. Yang, X. Yang, Y. Fan, Electrocatalysis, 2015, 6, 255-262.

[25] Z. Y. Bai, Q. Zhang, J. Lv, S. J. Chao, L. Yang, J. L. Qiao, Electrochim. Acta, 2015, 177, 107-112.

[26] M. F. Philips, A. I. Gopalan, K. P. Lee, Catal. Commun., 2011, 12, 1084-1087.

[27] H. B. Wang, L. Thia, N. Li, X. M. Ge, Z. L. Liu, X. Wang, ACS Catal., 2015, 5, 3174-3180.

[28] J. S. Moon, Y. W. Lee, S. B. Han, K. W. Park, Int. J. Hydrogen Energy, 2014, 39, 7798-7804.

[29] F. P. Hu, P. K. Shen, J. Power Sources, 2007, 173, 877-881.

[30] N. A. Yashtulov, S. S. Gavrin, A. A. Revina, V. R. Flid, Russ. Chem. Bull., 2010, 59, 1482-1487.

[31] S. Ha, R. Larsen, R. I. Masel, J. Power Sources, 2005, 144, 28-34.

[32] R. Larsen, S. Ha, J. Zakzeski, R. I. Masel, J. Power Sources, 2006, 157,
78-84.

[33] W. J. Wen, C. Y. Li, W. P. Li, Y. Tian, Electrochim. Acta, 2013, 109, 201-206.

[34] S. D. Yang, C. M. Shen, X. J. Lu, H. Tong, J. J. Zhu, X. G. Zhang, H. J. Gao, Electrochim. Acta, 2012, 62, 242-249.

[35] B. Seger, P. V. Kamat, J. Phys. Chem. C, 2009, 113, 7990-7995.

[36] K. S. Novoselov, A. K. Geim, S. V. Morozov, D. Jiang, Y. Zhang, S. V. Dubonos, I. V. Grigorieva, A. A. Firsov, Science, 2004, 306, 666-669.

[37] C. Berger, Z. M. Song, X. B. Li, X. S. Wu, N. Brown, C. Naud, D. Mayou, T. B. Li, J. Hass, A. N. Marchenkov, E. H. Conrad, P. N. First, W. A. de Heer, Science, 2006, 312, 1191-1196.

[38] A. Dato, V. Radmilovic, Z. Lee, J. Phillips, M. Frenklach, Nano Lett., 2008, 8, 2012-2016.

[39] E. Antolini, Appl. Catal. B, 2012, 123, 52-68.

[40] L. Y. Jiao, L. Zhang, L. Ding, J. Liu, H. J. Dai, Nano Res., 2010, 3, 387-394.

[41] C. Vallés, C. Drummond, H. Saadaoui, C. A. Furtado, M. He, O. Roubeau, L. Ortolani, M. Monthioux, A. Pénicaud, J. Am. Chem. Soc., 2008, 130, 15802-15804.

[42] J. Yang, C. G. Tian, L. Wang, H. G. Fu, J. Mater. Chem., 2011, 21, 3384-3390.

[43] Y. J. Li, Y. J. Li, E. B. Zhu, T. McLouth, C. Y. Chiu, X. Q. Huang, Y. Huang, J. Am. Chem. Soc., 2012, 134, 12326-12329.

[44] D. C. Marcano, D. V. Kosynkin, J. M. Berlin, A. Sinitskii, Z. Z. Sun, A. Slesarev, L. B. Alemany, W. Lu, J. M. Tour, ACS Nano, 2010, 4, 4806-4814.

[45] Y. Wang, H. L. Liu, L. Wang, H. B. Wang, X. Du, F. Wang, T. Qi, J. M. Lee, X. Wang, J. Mater. Chem. A, 2013, 1, 6839-6848.

[46] K. Q. Wang, B. Wang, J. F. Chang, L. G. Feng, W. Xing, Electrochim. Acta, 2014, 150, 329-336.

[47] M. Vafaei, M. Rezaei, S. H. Tabaian, F. Mahboubi, D. F. Haghshenas, J. Solid State Electrochem., 2015, 19, 289-298.

[48] X. Zhang, J. X. Zhu, C. S. Tiwary, Z. Y. Ma, H. J. Huang, J. F. Zhang, Z. Y. Lu, W. Huang, Y. P. Wu, ACS Appl. Mater. Interfaces, 2016, 8, 10858-10865. 
[49] A. Bin Yousaf, M. Imran, A. Zeb, X. Xie, K. Liang, X. Zhou, C. Z. Yuan, A. W. Xu, Catal. Sci. Technol., 2016, 6, 4794-4801.

[50] K. Fu, Y. Wang, L. C. Mao, J. H. Jin, S. L. Yang, G. Li, Electrochim. Acta, 2016, 215, 427-434.

[51] T. Z. Hong, Q. Xue, Z. Y. Yang, Y. P. Dong, J. Power Sources, 2016, 303, 109-117.

[52] W. Luo, W. H. Doh, Y. T. Law, F. Aweke, A. Ksiazek-Sobieszek, A. Sobieszek, L. Salamacha, K. Skrzypiec, F. Le Normand, A. Machocki, S. Zafeiratos, J. Phys. Chem. Lett., 2014, 5, 1837-1844.

[53] Y. J. Huang, X. C. Zhou, J. H. Liao, C. P. Liu, T. H. Lu, W. Xing, Electrochem. Commun., 2008, 10, 1155-1157.

[54] U. Holzwarth, N. Gibson, Nat. Nanotechnol., 2011, 6, 534.

[55] S. Stankovich, D. A. Dikin, R. D. Piner, K. A. Kohlhaas, A. Kleinhammes, Y. Y. Jia, Y. Wu, S. B. T. Nguyen, R. S. Ruoff, Carbon, 2007, 45, 1558-1565.

[56] X. M. Chen, G. H. Wu, J. M. Chen, X. Chen, Z. X. Xie, X. R. Wang, J. Am. chem. Soc., 2011, 133, 3693-3695.

[57] S. D. Yang, C. M. Shen, Y. Y. Liang, H. Tong, W. He, X. Z. Shi, X. G. Zhang, H. J. Gao, Nanoscale, 2011, 3, 3277-3284.
[58] X. Q. Gao, F. M. Li, Y. M. Li, S. N. Li, Y. Chen, J. M. Lee, J. Power Sources, 2015, 280, 491-498.

[59] D. A. Shirley, Phys. Rev. B, 1972, 5, 4709-4714.

[60] Q. S. Chen, Z. N. Xu, S. Y. Peng, Y. M. Chen, D. M. Lv, Z. Q. Wang, J. Sun, G. C. Guo, J. Power Sources, 2015, 282, 471-478.

[61] Y. J. Guo, S. J. Guo, J. T. Ren, Y. M. Zhai, S. J. Dong, E. K. Wang, ACS Nano, 2010, 7, 4001-4010.

[62] R. Kou, Y. Y. Shao, D. H. Mei, Z. M. Nie, D. H. Wang, C. M. Wang, V. V. Viswanathan, S. Park, I. A. Aksay, Y. H. Lin, Y. Wang, J. Liu, J. Am. Chem. Soc., 2011, 133, 2541-2547.

[63] G. X. Yang, Y. Chen, Y. M. Zhou, Y. W. Tang, T. H. Lu, Electrochem. Commun., 2010, 12, 492-495.

[64] R. N. Singh, R. Awasthi, Catal. Sci. Technol., 2011, 1, 778-783.

[65] Y. Y. She, Z. G. Lu, W. G. Fan, S. Jewell, M. K. H. Leung, J. Mater. Chem. A, 2014, 2, 3894-3898.

[66] J. Q. Zeng, S. N. Sun, J. P. Zhong, X. F. Li, R. X. Wang, L. N. Wu, L. Wang, Y. J. Fan, Int. J. Hydron. Energy, 2014, 39, 15928-15936.

[67] D. D. Tu, B. Wu, B. X. Wang, C. Deng, Y. Gao, Appl. Catal. B, 2011, 103, 163-168.

\title{
利用石墨烯-炭黑组成的二元碳载体增强甲酸在钯催化剂上电化学氧化的活性
}

\author{
吕美英，李文鹏，刘慧玲，温文娟，董 广，刘菁桦，彭凯臣 \\ 齐鲁工业大学化学与制药工程学院, 山东济南250353
}

摘要: 本文采用“一锅法”将氧化石墨烯 $(\mathrm{GO})$ 、炭黑 $(\mathrm{C})$ 和钯离子用 $\mathrm{NaBH}_{4}$ 共还原, 制备了石墨烯-炭黑二元载体 $(\mathrm{Gr}-\mathrm{C})$ 负载的 钯催化剂 $(20 \% \mathrm{Pd} / \mathrm{Gr}-\mathrm{C})$, 用于催化甲酸的电氧化反应. 电化学测试结果表明, 前驱体 $\mathrm{GO}$ 和 $\mathrm{C}$ 的质量比为 $3: 7$ 的 $\mathrm{Pd} / \mathrm{Gr}_{0.3} \mathrm{C}_{0.7}$ 催 化剂催化活性最好, 它的峰电流密度 $\left(102.14 \mathrm{~mA} \mathrm{mg}_{\mathrm{Pd}}{ }^{-1}\right.$ )约为 $\mathrm{Pd} / \mathrm{C}$ 催化剂(34.40 mA mg ${ }_{\mathrm{Pd}}^{-1}$ )的3倍, 为钯/石墨烯催化剂 $\left(\mathrm{Pd} / \mathrm{Gr}, 38.50 \mathrm{~mA} \mathrm{mg}{ }_{\mathrm{Pd}}^{-1}\right)$ 的 2.6 倍. 甲酸在 $\mathrm{Pd} / \mathrm{Gr}_{0.3} \mathrm{C}_{0.7}$ 催化剂电极直接氧化时的峰电位比 $\mathrm{Pd} / \mathrm{C}$ 催化剂的峰电位负移约 120 $\mathrm{mV}$, 比 $\mathrm{Pd} / \mathrm{Gr}$ 催化剂的峰电位负移约 $70 \mathrm{mV}$. 采用透射电子显微镜(TEM)、扫描电子显微镜(SEM)、X 射线衍射(XRD)、X 射线光电子能谱(XPS)、拉曼光谱、电感耦合等离子发射光谱(ICP-AES)等手段对催化剂进行了表征. 从SEM图像可以观 察到, 球形的炭黑团簇聚集在具有褶皱的石墨烯面上, 形成了炭黑团簇/石墨烯三维立体结构, 有效地抑制了相邻石墨烯层 在范德华力作用下的吸引聚集和堆叠造成的石墨烯表面积减小, 减小了单层石墨烯叠合成为多层石墨所造成的导电性损 失, 避免了相邻石墨烯片叠合形成封闭空间, 有助于反应物和产物分子的运动. 载体的三维结构使反应物分子更容易到达 钯纳米粒子, 有利于催化性能的提高. XPS结果也证实了二元Gr-C载体对Pd催化的促进作用. $\mathrm{Pd} / \mathrm{Gr}_{0.3} \mathrm{C}_{0.7}$ 催化剂的Pd $3 d_{5 / 2}$ 峰发生了右移, 表明 Pd $3 d$ 电子结合能正移, Pd $3 d$ 电子云密度降低. 具有较低的 $3 d$ 电子云密度的 Pd不易与甲酸氧化过程中 吸附的中间体 $(\mathrm{COOH})_{\mathrm{ads}}$ 结合, 钯催化剂上 $(\mathrm{COOH})_{\mathrm{add}}$ 表面覆盖率降低, 从而使甲酸更容易直接脱氢氧化生成 $\mathrm{CO}_{2}$, 有利于甲 酸通过直接途径进行电化学氧化.

与 $\mathrm{Pd} / \mathrm{C}, \mathrm{Pd} / \mathrm{Gr}$ 相比, $\mathrm{Pd} / \mathrm{Gr}_{0.3} \mathrm{C}_{0.7}$ 催化剂对甲酸电氧化有最好的催化活性. $\mathrm{Pd} / \mathrm{Gr}_{0.3} \mathrm{C}_{0.7}$ 催化剂优异的催化活性可归因于 其内在的三维纳米结构: 炭黑团簇有效地抑制了石墨烯纳米片的聚集, 保持了其大的比表面积和高导电性, 促进了反应物 和产物分子的运动. 此外, Pd纳米粒子与二元载体之间的强相互作用降低了Pd的 $3 d$ 电子云密度, 使甲酸氧化主要经直接途 径进行. 本文证实了钯金属和石墨烯-炭黑二元载体之间的强相互作用, 提供了简单和高性价比的方法以提高钯基催化剂 的活性, 有利于工业化的应用.

关键词: 二元碳载体; 钯; 石墨烯; 炭黑; 甲酸氧化; 燃料电池

收稿日期: 2016-12-25. 接受日期: 2017-04-06. 出版日期: 2017-05-05.

*通讯联系人. 电话: (0531)89631208; 传真: (0531)89631207; 电子信箱: liwenpeng@qlu.edu.cn, wenpengli75@163.com

基金来源：山东省自然科学基金(ZR2016BM31); 济南市高校自主创新计划项目(201311035).

本文的英文电子版由Elsevier出版社在ScienceDirect上出版(http://www.sciencedirect.com/science/journal/18722067). 